\title{
New Narration Explosion of Shi Tiesheng's " Notes on Principles "
}

\section{Zhang Yi}

\author{
Xi'an Fanyi University, Xi'an, 710105
}

\section{Key Words: Shi Tiesheng ; Notes on Principles; Narrative style}

\begin{abstract}
Shi Tiesheng was a famous contemporary writer in China and had significant influence on literary circles. He accomplished a lot of workers in his lifetime and " Notes on Principles " was one of his important workers. Comparing with traditional narrative novels, " Notes on Principles " has distinctive features in narration, and makes breakthroughs and developments in narrative discourse, narrative structure, and narrative language.

Shi Tiesheng accomplished so many influential novels, contributing a lot to Chinese literary circles. " Notes on Principles " was the most important representative of Shi Tiesheng. It's the first full-length novel that was finished on wheel chair after the writer had been physically handicapped and was published on the magazine " Harvest " in 1996. " Notes on Principles " elaborates influences of social changes from 1950's on different crowds, mainly including poets, disabled people, doctors, women teachers, painters and female directors. In the novel, there is not only thinking about life and death, but also understanding of vacancy. It can be said that this novel is sort of the writer's biography, through a series of narrations, shearing his life experiences and feelings with the public. The novel has distinctive feature and method in writing, especially in narrative style, and it is different with narrative style of traditional novels in the following aspects:
\end{abstract}

\section{Features in Narrative Style}

In traditional literary works, outright stating is the mainly linguistic style embodied in narration. Because from traditional stand, narration is just telling a story, and retelling something, which is real or imaginative. But with the era development, the idea of narration has changed to some extent, shifting from " story oriented " to " narration oriented ". So outright stating is no more the only style of expression, and virtuality, as a new narrating state, is drawing more and more passions. Nowadays, narration is gradually stressing less than ever before, imagining more on things that would take place in the future, and putting more importance on narrator's emotion and attitude. In the novel " Notes on Principles " , hypothetical narrative style was combined with outright stating style in some degrees, and this is the most dominant feature of the novel. On the one hand, the writer introduced a finished real story by using the outright stating style of narration, on the other hand, the writer placed some changes on stories narrated in hypothetical narration state, making the whole story linked with the narrator in some ways, and expressed his inner true feelings through these imaginative stories narrated in the novel.

In the novel " Notes on Principles ", the writer mainly narrated some finished and real stories by using outright narrative style. This kind of expression and narration aims at exploring difficult 
positions faced in life. The novel is composed by a series of little stories, but each of them is a presence of difficult positions in life. In other words, every little story is a philosophic theory that is worth thinking. The narrator of the novel deeply thought living issues through narrating these stories. In the novel, major representatives of outright linguistic style include $\mathrm{Z}$ fail to go up to the neat grade, C get married, O fell in love the painter, etc. C, as a disabled people, had no link with love for a long time, but he never surrendered to destiny and all along yearned for love. After continuous seeking, he finally married a woman and completed his wish. Enclosing with the disabled people and love, the whole novel discussed a lot on them, and this is also an very important ideology background for the novel. Meanwhile, the novel deeply discussed difference and equality issues by comparing stories of $\mathrm{O}$ and $\mathrm{Z}$. Because of these differences, some concrete positive or negative problems raised and were worth our thinking. Except stories of $\mathrm{C}, \mathrm{O}, \mathrm{Z}$, the novel also stated many other people's stories. Through these outright narrations, we have a knowledge of the story of every character and have a deep feeling about difficult situations faced by them and the battle they fight against the dilemmas, and finally have better understanding of love and beauty.

The purpose of hypothetical narrative style in the novel is to connect footpoint of narration with narrator's life. Description of difficult positions faced by kinds of characters and fight against it is actually narration of dilemmas faced by the writer. Observing dilemmas of the writer and human beings made transformation in some ways. Through hypothetical narrative style, the novel on one hand denied facticity of stories narrated in the novel and well reflected ideas of narrator; on the other hand it passed the readers an idea that nothing is impossible, so as to deepen their understanding and feelings of life. In the novel, hypothetical narrative style is obvious, and many descriptive words such as possible, hope, maybe are used many times. In this way, every possibility is exhibited and compared as more as possible. From it, we have further realization in life and living.

In a word, through " outright linguistic style " we can have a knowledge of uniqueness of characters and concretness of the story, but through hypothetical narrative style, disrupt stories of many characters can be embodied in one person. Intermixed use of the two linguistic styles brings readers to philosophic thinking in some degrees, and it pushes us to further explore difficult positions in life while introduce the colorful world to us.

\section{Features in Narrative Structure}

In the novel " Notes on Principles " , features in narrative structure is obvious, this fully embodies the elements in Chinese traditional novels, including circle repeats and the end echoes the beginning. Except for this, this is also an expression of spiral upward, and it can be said that this is the use of the law of negation of negation.

The novel " Retreat Notes " learned such features as the circle repeats and the end echoes the beginning and symmetry from Chinese traditional novels. Among Chinese traditional novels, metaphor is a method which is used often by the writer, and this can be discovered in " Notes on Principles " . For example, the whole story is used in metaphor in the first chapter of the novel. 
The content probably relevant to the novel can be tracked from the description of the first chrpter. Apart from the reflection of metaphor, the first and second chapter of the novel echo the last chapter in some degrees. This is not only the expression of the beginning corresponding the end character in structure, meanwhile, echoes the theme of disability and love in content.

In the whole novel, segmental feature reflected obviously in the narration of relations between stories. Connections between stories and narration of inner plots are delicate, and this reflects features of traditional Chinese novels. At the same time, it also reflects some features that are totally differ to traditional Chinese culture. Instead of similarity between these stories, the novel mainly focuses on different attentions that had been put on them. However, similarity reflected in traditional novels is an circular regress narration feature. Difference is an expression of inner connection, and fully expresses the important feature of negation of negation. " Notes on Principles " not only has the feature of traditional Chinese novels, but also has the features of western novels. These features fully expresses the combination of Chinese and Western novels in some degrees and brings good feelings of beauty.

\section{Features in Narration Language}

In the novel " Notes on Principles " , features in narration language aredominant. combination of dialogues and discourse repeatition is the main way of language expression. Discourse repeatition is an emphasis for the novel's theme and a reflection for narrative rhythm. The dialogues between characters can help us know better about the process that they pursuing dreams or ideas.

In the novel " Notes on Principles " , repeatition is one of the important features, including plot repeatition, intention repeatition, scene repeatition. Specific description of dilemmas and process of fight against dilemmas facilitates readers to understand better about the novel's theme. There are many repeatition places in the novel, for example plot repeation including repeation of the gate of childhood, repeatition of north China in intention, ploy repeatition and sex repeatition. These repeatitions help us to have a deep understanding of the main idea that the writer want to express, that is the writer had to face and struggle with a series of difficult positions, and longed to defeat these difficulties and achieve his dream. Either dilemmas of dreams are eternal for people, and struggling in the process is eternal too.

In the novel " Notes on Principles " , there are many dialogues, but they are differ from daily talks. dialogues between characters seemed simple in outside appearance but rich in connotation and are worth exploring and thinking. These dialogues reveal human nature and lead us to understand life difficulties and learn how to defeat these difficulties. In the novel " Notes on Principles " , communication and argument of dialogues facilitates readers to have a further understanding of life difficulties and embodies the light of being in some degrees. These dialogues not only include talks between painter and female teacher on differences and equality, but also contain discussions between lovers and poet about love and sex, talks between unknown man and poet on "peeper ", and discussion between uncle $\mathrm{Z}$ and " me " on "betrayer " issues. Conversations between these characters properly present problems that people faced in their life and 
express the struggling process that they go for their dreams. If poured unremitting efforts, the light of being will surely come to you.

" Notes on Principles " , as one of the representative works of Shi Tiesheng, brought us profound feelings and thoughts. The narration of the novel shift focus from " story " to " narration " , and this is an important feature that fully reflected in the novel. It's narration feature is an classic combination of western and Chinese novels, and is worth our further studying and analysis.

\section{References}

[1] Xie Jianpeng: " Narration Theories of Full-Length Novel of Shi Tiesheng " [D].Guangxi Normal University, 2013;

[2] Zhang Huiping: " Analysis of Polyphony in 'Wu Xu Notes’of Shi Tiesheng. [D].Henan University, 2011;

[3] Su Huapu: " Narratology Research of 'Wuxu Notes’ " [D].Shandong Normal University, 2010;

[4] Zhang Junli: " Research of Language Style in Shi Tiesheng’s Novel " [D].Guangzhou University, 2012;

[5] Song Yunfang: " Another Writing of Love: Narration Ethics of Love in Shi Tiesheng's 'Wuxu Notes' " ; [J].Journal of Nanchang University (Humanities and Social Sciences) , Issue No.S1, 2010;

[6] Lu Lixia: " Time Strategies of Narration in 'WuXu Notes' " [J].Literature and Art Criticism, Issue No.9， 2012;

[7] Zhang Ning: " Shi Tiesheng’s Words: Ban Ruoyi’s comments on 'Wuxu Notes' "Contemporary Writers Review, Issue No.3, 1997;

[8] Zhang Luli: "Construction and Features of Shi Tiesheng's Philosophic Thought Style "[J]. Journal of Nanchang University（Humanities and Social Sciences）， Issue No.1， 2008.

\section{Brief Introduction of the Author:}

Zhang Yi(1983- ) male, from Yicheng County, Shan Xi Province, teacher of Xi'an Fanyi University, master of arts. Research direction: research of Chinese \& western literature and cultural comparison. 